\title{
Effects of hydrolyzed cottonseed protein supplementation on performance, blood metabolites, gastrointestinal development, and intestinal microbial colonization in neonatal calves
}

\author{
B. Dolatkhah, ${ }^{1}$ G. R. Ghorbani, ${ }^{1 *}$ M. Alikhani, ${ }^{1}$ F. Hashemzadeh, ${ }^{1}$ A. H. Mahdavi, ${ }^{1}$ A. Sadeghi-Sefidmazgi, ${ }^{1}$ \\ H. Erfani, ${ }^{1}$ and P. Rezamand ${ }^{2 *}$ \\ ${ }^{1}$ Department of Animal Sciences, College of Agriculture, Isfahan University of Technology, Isfahan 84156-83111, Iran \\ ${ }^{2}$ Department of Animal and Veterinary Science, University of Idaho, Moscow 83844
}

\begin{abstract}
The objective of this study was to investigate the effects of an enzymatically hydrolyzed cottonseed protein (HCSP) as a peptide source on performance, blood metabolites, gastrointestinal development, and intestinal microbes. Forty-eight newborn Holstein calves were randomly assigned to 1 of the 4 dietary treatments including $0,2,4$, and $6 \%$ of HCSP (dry matter basis). All calves received the same amount of pasteurized whole milk, weaned on d 56 of the experiment, and the study was concluded on d 70. Data were analyzed using PROC MIXED in SAS (SAS Institute Inc., Cary, $\mathrm{NC}$ ) as a randomized complete block design with linear and quadratic contrasts. Results showed that increased amount of HCSP linearly decreased the starter intake during the postweaning (d 57 to 70 ) and overall period (d 1 to 70). In addition, when dietary HCSP increased during the overall period, average daily gain tended to linearly decrease. All skeletal growth variables also linearly decreased as dietary HCSP increased at the end of the study, except for body length, which did not differ among the treatments. Serum cortisol concentration was higher in calves supplemented with $6 \%$ of HCSP at weaning and at the end of the study. This indicates that these calves may have experienced a stressful condition compared with calves in other treatments. Total antioxidant capacity was quadratically affected by HCSP supplementation; calves fed 2 and $4 \%$ of HCSP diets had the highest total antioxidant capacity, whereas calves fed 0 and $6 \%$ HCSP diets had lower total antioxidant capacity at weaning and at end of the study. Calves supplemented with $6 \%$ HCSP had lower empty reticulo-rumen and omasum weights and rumen wall thickness compared with calves in other
\end{abstract}

\footnotetext{
Received July 19, 2019.

Accepted February 3, 2020.

*Corresponding authors: ghorbani@cc.iut.ac.ir and rezamand@ uidaho.edu
}

treatments at the end of the study. In conclusion, supplementation of HCSP at the rate of $2 \%$ of starter diet enhanced antioxidant status without any detrimental effects on the performance and metabolic status of calves, whereas greater inclusion rates impaired starter intake and growth of calves, and exposed them to a stressful status.

Key words: enzymatic hydrolyzed cottonseed protein, dairy calf, performance, rumen development, antioxidant capacity

\section{INTRODUCTION}

Rearing healthy calves is crucial for the long-term success and future profitability and sustainability of a dairy farm. During the first weeks of calves' lives, many nutritional, physiological, and environmental stressors affect dairy calves, which expose them to an increased risk of disease, poor well-being, or reduced production performance later in life (Windeyer et al., 2014; Hulbert and Moisá, 2016). Most of these stressors appear inevitable but are manageable in calf production systems (Hulbert and Moisá, 2016). Some evidence indicates that some stressors may induce an oxidative stress condition, resulting in an impaired immune system, growth, metabolism, and health in neonatal dairy calves (Mutinati et al., 2014). For instance, supplementing vitamin $\mathrm{E}$ or a commercial antioxidant to transport-stressed feedlot cattle improved their health and growth (Burke et al., 2009). Therefore, some management and nutritional strategies should be developed to minimize the effects of stressors and optimize the calf health and welfare at this early stage of life (Hulbert and Moisá, 2016).

Cottonseed meal (CSM) is used in dairy rations because of its lower price, limited use in nonruminant diets, and greater bypass protein when compared with soybean meal (Coppock et al., 1987). In spite of low Lys and Met concentrations and variable gossypol content of CSM, inclusion of CSM in the diets 
of high-producing dairy cows resulted in comparable performance responses with those fed diets containing canola or soybean meals (Blackwelder et al., 1998; Maesoomi et al., 2006). This leads to a more economic and sustainable dairy production system. In contrast to dairy cows, however, the use of CSM as a protein source for neonatal calves is not recommended because dairy calves function primarily as monogastric animals during the first 1 to 2 mo of life. Therefore, nutritional deficiencies or lower digestibility of CSM limit its use in young calves (Fiems et al., 1986; Zelski et al., 1995).

Recent findings suggest that robust chemical, enzymatic, or microbial hydrolysis of proteins to small peptides could enhance the nutritional quality and reduce the anti-nutritional factors in CSM (Hou et al., 2017). In monogastric animals, adding peptides to diets improved palatability, growth, feed efficiency, and health (Kim et al., 2010). Furthermore, when calves were fed hydrolysate of soy protein isolate $(19.7 \%$, DM basis), growth performance did not differ compared with those fed skim milk powder. This indicates the enhanced availability and reduced anti-nutritional factors of protein hydrolysates (Lalles et al., 1995). In adult ruminants, it has been assumed that increased supply of preformed AA and peptides would enhance the ruminal microbial growth and efficiency, especially when the diet contained an excess amount of readily fermentable carbohydrate (Oh et al., 1999).

In addition, some peptides of plant or animal sources exhibit antioxidant, antihypertensive, and immunomodulatory activities. These peptides, which confer biological functions beyond their nutritional values, are called bioactive peptides (Hou et al., 2017). Gao et al. (2010) reported that Neutrase-liberated peptides from cottonseed protein had strong antioxidant activity and might be useful as a food additive and nutrient. It has been recently shown that partial replacement of soybean meal with fermented CSM, which is rich in small size peptides, enhanced the nutritional value of CSM, resulting in improved growth performance, serum immunoglobulin, and oxidative status, as well as cecal microbial balance in broilers (Tang et al., 2012; Sun et al., 2013).

It is hypothesized that supplementation of enzymatic hydrolyzed cottonseed protein as a nutritional and functional additive may alleviate some aspects of metabolic stresses in neonatal calves and improve their performance responses. Therefore, the objective the present study was to examine, for the first time, the effects of supplementing incremental levels of enzymatic hydrolyzed cottonseed protein, rich in bioactive peptides, on the performance, metabolic parameters, ruminal nitrogen metabolism, and rumen development of neonatal dairy calves.

\section{MATERIALS AND METHODS}

This experiment was conducted on a local dairy farm (Goldasht-Nemooneh Agri-Animal Production Co., Isfahan, Iran) under the protocols approved by the Animal Care and Use Committee of the Iranian Council of Animal Care (1995), from October to December 2017.

\section{Calves, Housing, and Diets}

Holstein calves $(40.4 \pm 2.13 \mathrm{~kg}$ of $\mathrm{BW}$; mean $\pm \mathrm{SD})$ were separated from their dams at birth, weighed, and placed in individual pens bedded with wood shavings. Calves were fed $4 \mathrm{~L}$ of colostrum within $3 \mathrm{~h}$ of birth. They were then fed transition milk at the standard feeding times (0800 and $1700 \mathrm{~h}$ ) unless when a calf was born within $3 \mathrm{~h}$ before the next standard feeding time. In this case, they first received colostrum and then at the subsequent transition milk feed was provided at the second upcoming standard feeding time. At $24 \mathrm{~h}$ after colostrum intake, blood samples were obtained from the jugular vein by venipuncture and serum total protein was measured as an indicator of passive transfer of immunity, using a Reichert AR200 digital handheld refractometer (Reichert Inc., Depew, NY). Calves with a serum protein level $>5.8 \mathrm{~g} / \mathrm{dL}$ were included in the study. A total of forty-eight 3-d-old calves were allocated to the study and were bucket-fed pasteurized waste milk (average composition of $11.5 \%$ DM, $2.8 \%$ $\mathrm{CP}$, and $3.2 \%$ fat). Milk was offered twice a day at 0900 and $1500 \mathrm{~h}$ from 0 to 50 and once a day from 51 to 56 d of study with an adjusted step-up/step-down milk feeding protocol as 5, 6, 5, and $3 \mathrm{~L}$ for wk 1-2, 3-4, 5-7, and 8, respectively. All calves were weaned at $56 \mathrm{~d}$ of experiment and the experiment was terminated at $\mathrm{d} 70$.

The experiment was performed in a randomized complete block design with 4 dietary treatments including $0,2,4$, and $6 \%$ of hydrolyzed cottonseed protein (HCSP) and 12 (6 males and 6 females) replicates for each treatment. Calves were blocked by sex and randomly allocated to 1 of 4 treatment groups. The HCSP used in this study was a commercial product, Fortide $\mathrm{C}$, produced from enzymatic hydrolysis of cottonseed protein as a source of small chain peptides (Mytech Biotech Co., Ltd., Chengdu City, China). Crude protein and $\mathrm{CF}$ contents of this product were 45 and $8 \%$, respectively. Cottonseed protein hydrolysates were categorized into 4 fractions according to their molecular weights, $<1,000,1,000-2,000,2,000-5,000$ and $>5,000$ Da by $48.9,21.1,17.5$, and $12.5 \%$ of total peptides, respectively, as reported by the manufacturer.

Amino acid profile relative to Lys content (known as ideal protein concept; Lys $=100$ ) in soybean meal, HCSP, different ratios of HCSP to soybean meal 
Table 1. Ratio of AA to Lys (\% of Lys) in soybean meal, hydrolyzed cottonseed protein (HCSP), or the different ratios of soybean meal (SBM) and HCSP compared with target AA profile of whole body of preruminant calves

\begin{tabular}{lcccccc}
\hline & & & & \multicolumn{3}{c}{ Ratio of HCSP to SBM } \\
\cline { 5 - 7 } AA & & & & & & \\
\cline { 5 - 6 } & Target $^{1}$ & SBM & HCSP & $2: 22.3$ & $4: 20.3$ & $6: 18.3$ \\
\hline Arg & 106 & 117 & 189 & 123 & 129 & 135 \\
His & 38.5 & 44.1 & 50.7 & 44.6 & 45.2 & 45.7 \\
Ile & 46.9 & 72.6 & 63.4 & 71.8 & 71.1 & 70.3 \\
Leu & 111 & 124 & 109 & 123 & 122 & 121 \\
Lys & 100 & 100 & 100 & 100 & 100 & 100 \\
Met & 28.6 & 23.1 & 26.2 & 23.3 & 23.5 & 23.8 \\
Phe & 58.3 & 83.7 & 89.7 & 84.2 & 84.7 & 85.2 \\
Thr & 61.2 & 63.3 & 55.5 & 62.7 & 62.9 & 61.4 \\
Trp & 18.8 & 20.1 & 17.4 & 19.8 & 19.6 & 19.4 \\
Val & 69.0 & 74.7 & 90.4 & 75.9 & 77.3 & 78.5 \\
\hline
\end{tabular}

${ }^{1}$ Based on whole-body AA composition of preruminant Holstein calves (Van Amburgh et al., 2015).

$(2: 22.3,4: 20.3$, and $6: 18.3)$ and target AA profile of the whole body of preruminant calves are presented in Table 1. The target profile for growth used was an unpublished estimate from M. E. Van Amburgh (Cornell University, Ithaca, NY). This profile was determined from the whole-body AA composition of 65- and 105$\mathrm{kg}$ preruminant Holstein calves (Van Amburgh et al., 2015). Diets were formulated to be isonitrogenous and isocaloric and met requirements (NRC, 2001) for calves (Table 2). The diets contained steam-flaked corn prepared as described by Plascencia and Zinn (1996) with a 3-mm pellet of other components plus chopped alfalfa hay $(7 \%)$ with a geometric mean particle size of 2.6 $\mathrm{mm}$. All calves had free access to clean, fresh water and the starter feed at all times. The offered feed was adjusted daily to achieve 5 to $10 \%$ orts.

\section{Data Collection and Sampling}

The offered and refused amounts of starter diets were measured daily for each calf to determine the starter intake and total DMI. Starter samples of each treatment were taken twice a month and kept frozen $\left(-20^{\circ} \mathrm{C}\right)$ for subsequent analyses. Calves weighed at birth, $3 \mathrm{~d}$

Table 2. The ingredients and chemical composition (\% of DM unless otherwise noted) of starter feeds

\begin{tabular}{|c|c|c|c|c|}
\hline \multirow[b]{2}{*}{ Item } & \multicolumn{4}{|c|}{$\begin{array}{c}\text { Hydrolyzed cottonseed } \\
\text { protein inclusion rate (\%) }\end{array}$} \\
\hline & 6 & 4 & 2 & 0 \\
\hline \multicolumn{5}{|l|}{ Ingredient } \\
\hline Steam-flaked corn & 40.5 & 40.5 & 40.5 & 40.5 \\
\hline Steam-rolled barley & 19.0 & 19.0 & 19.0 & 19.0 \\
\hline Soybean meal ${ }^{1}$ & 18.3 & 20.3 & 22.3 & 24.3 \\
\hline Hydrolyzed cottonseed protein ${ }^{1}$ & 6.00 & 4.00 & 2.00 & 0.00 \\
\hline Premix $^{1,2}$ & 14.4 & 14.4 & 14.4 & 14.4 \\
\hline Salt $^{1}$ & 0.49 & 0.49 & 0.49 & 0.49 \\
\hline Calcium carbonate $^{1}$ & 1.23 & 1.23 & 1.23 & 1.23 \\
\hline \multicolumn{5}{|l|}{ Chemical composition } \\
\hline $\mathrm{DM}$ & 90.0 & 90.0 & 90.0 & 90.0 \\
\hline $\mathrm{CP}$ & 21.7 & 21.8 & 21.8 & 21.9 \\
\hline Ether extract & 3.60 & 3.50 & 3.50 & 3.50 \\
\hline $\mathrm{NDF}$ & 15.2 & 15.6 & 16.0 & 16.3 \\
\hline $\mathrm{Ca}^{3}$ & 0.94 & 0.88 & 0.82 & 0.80 \\
\hline $\mathrm{P}^{3}$ & 0.49 & 0.49 & 0.49 & 0.48 \\
\hline $\mathrm{ME}^{3}$ (Mcal/kg) & 2.91 & 2.95 & 2.97 & 3.00 \\
\hline $\mathrm{NE}_{\mathrm{g}}{ }^{3}$ (Mcal/kg) & 1.34 & 1.34 & 1.33 & 1.33 \\
\hline
\end{tabular}

${ }^{1}$ Protein sources of this premix included $1.5 \%$ extruded soybean, $2 \%$ corn gluten meal, and $24 \%$ soybean meal, and all ingredients were pelleted.

${ }^{2}$ Contained per kilogram of supplement (unless noted): $\mathrm{DM}=93 \%, \mathrm{CP}=29 \%$, fat $=6.5 \%, \mathrm{ME}=2.31 \mathrm{Mcal}$, $\mathrm{NE}_{\mathrm{G}}=0.85 \mathrm{Mcal}, \mathrm{NDF}=17.5 \%, \mathrm{Ca}=0.65 \%, \mathrm{P}=0.77 \%, \mathrm{NFC}=29 \%, \mathrm{Mg}(\mathrm{g})=2, \mathrm{~K}(\mathrm{~g})=0.99, \mathrm{Na}(\mathrm{g})=$ $1.6, \mathrm{Cl}(\mathrm{mg} / \mathrm{kg})=0.1, \mathrm{Co}(\mathrm{mg} / \mathrm{kg})=23, \mathrm{Mn}(\mathrm{mg} / \mathrm{kg})=43, \mathrm{Se}(\mathrm{mg} / \mathrm{kg})=0.1, \mathrm{Zn}(\mathrm{mg} / \mathrm{kg})=43,12,000 \mathrm{IU}$ of vitamin A, 5,000 IU of vitamin D, and $100 \mathrm{IU}$ of vitamin E.

${ }^{3}$ Calculated from the NRC (2001) model. 
after birth, and then every 2 wk until the end of the experiment before the morning milk feeding. Starter intake, total DMI (milk and starter diet), ADG, and feed efficiency ( $\mathrm{kg}$ of BW gain per $\mathrm{kg}$ of total DMI) were calculated for wk 1 to 8 (preweaning period), 9 to 10 (postweaning period), and 1 to 10 (total trial period) as performance-related measures.

Body measurements including body height and length, width and height of hip, and heart girth were measured as described by Mirzaei et al. (2016) at the beginning of the experiment, at the weaning day, and at the end of the experiment. Observational health score data were collected every $2 \mathrm{~d}$ before the morning milk feeding during the experimental period. Coughing, nasal discharge, ear disposition, eye discharge, and fecal consistency were scored according to the University of Wisconsin calf health scoring chart on a scale of 0 to 3 (https://www.vetmed.wisc.edu/fapm/svm-dairy-apps/ calf-health-scorer-chs/). Fecal scores were established as (0) normal, (1) semi-formed, pasty, or both, (2) loose but stays on top of bedding, and (3) watery or sifts through the bedding, or both. Ear scores were (0) normal, (1) ear flick or head shake, (2) slight unilateral droop, and (3) head tilt or bilateral droop. Eye scores were (0) normal, (1) small amount of ocular discharge, (2) a moderate amount of bilateral discharge, and (3) heavy ocular discharge. Nasal scores were (0) normal serous discharge, (1) small amount of unilateral cloudy discharge, (2) bilateral or cloudy (or both) or excessive mucus discharge, and (3) copious bilateral mucopurulent discharge.

Blood samples were obtained for biochemical analysis from the jugular vein of calves with vacuum tubes on $\mathrm{d} 28,56$, and 70 approximately $1 \mathrm{~h}$ before the first daily milk feeding. Following the blood collection, samples were transferred to the laboratory within $1 \mathrm{~h}$, the serum was separated by centrifuging at 1,000 $\times$ $g$ for $20 \mathrm{~min}$, and was kept at $-20^{\circ} \mathrm{C}$ until analyses. The concentration of serum glucose, cholesterol, blood urea-N, triglyceride, total protein, albumin, alanine aminotransferase (ALT) and aspartate aminotransferase (AST) were measured by an autoanalyzer (Abbott Alcyon 300, Abbott Park, IL) using commercial kits (Pars Azmoon Co., Tehran, Iran) according to the manufacturer's instructions. Before the analysis, autoanalyzer was calibrated with the control sera N and $\mathrm{P}$ (TrueLab N and TrueLab P, respectively; Pars Azmoon Co.) and a calibrator solution (TrueCal U, Pars Azmoon Co.). Total antioxidant capacity and BHB of sera were determined by commercial colorimetric kits (Randox Laboratories Ltd., Ardmore, UK) using the same autoanalyzer. Globulin concentrations were obtained by deducting albumin from total protein. Malondialdehyde levels were measured using the thio- barbituric acid reactive substances method previously described by Meagher and FitzGerald (2000). Serum insulin and cortisol levels were measured using ELISA kit (Monobind Inc., Lake Forest, CA). Intra- and interassay coefficients of variation for measuring insulin were 6.9 and $8.2 \%$, respectively. In addition, serum triiodothyronine and thyroxine were analyzed by ELISA (ELISA Kit, Pishtaz-Teb Co., Tehran, Iran).

For hematologic analysis (complete blood count), blood samples were collected in tubes coated with EDTA/K3, mixed carefully several times, kept on ice, and immediately sent to the laboratory on d 70 of the experiment. Some complete blood count indices such as red blood cell count, mean corpuscular volume, mean corpuscular hemoglobin, mean corpuscular hemoglobin concentration, white blood cell count, and number of platelets were measured by an automated hematology analyzer (Sysmex XN-1000, Kobe, Japan).

\section{Rumen Fluid Sampling for $\mathrm{pH}$ and Peptides Analyses}

Ruminal contents were collected approximately $4 \mathrm{~h}$ postfeeding using a stomach tube at 35 and $70 \mathrm{~d}$ of age. Rumen fluid $\mathrm{pH}$ was determined immediately using a pH meter (HI 8314 membrane $\mathrm{pH}$ meter, Hanna Instruments, Villafranca, Italy). Ruminal contents were subsequently squeezed through 4 layers of cheesecloth to collect $10 \mathrm{~mL}$ of rumen fluid samples in tubes, and then were immediately transferred to the laboratory with ice and stored at $-20^{\circ} \mathrm{C}$. For ammonia- $\mathrm{N}$ and trichloroacetic acid- and tungstic acid-soluble $\mathrm{N}$, rumen fluid was centrifuged at $1,000 \times g$ for $10 \mathrm{~min}$ at $4^{\circ} \mathrm{C}$ to eliminate small particles and rumen protozoa. The supernatant was decanted into a new tube and centrifuged again at $10,000 \times g$ for $30 \mathrm{~min}$ at $4^{\circ} \mathrm{C}$ to discard rumen bacteria (Choi et al., 2002). Then, the supernatant was divided into three $2-\mathrm{mL}$ aliquots for measuring ammonia N, trichloroacetic acid-soluble N (TCA-N), and tungstic acid-soluble N (TA-N) as described by Busquet et al. (2006). For ammonia-N determination, a 2-mL subsample of filtered fluid was acidified with $2 \mathrm{~mL}$ of $0.2 \mathrm{~N} \mathrm{HCl}$ and frozen for subsequent analysis as described by Broderick and Kang, (1980). For TA-N analyzing, a 2-mL subsample of filtered fluid was added to $0.5 \mathrm{~mL}$ of $10 \%$ (wt/vol) sodium tungstate and $0.5 \mathrm{~mL}$ of $1.07 \mathrm{~N}$ sulfuric acid. Tubes were allowed to stand at $5^{\circ} \mathrm{C}$ for $4 \mathrm{~h}$ and then centrifuged at $9,000 \times$ $g$ for 15 min. The supernatant was frozen until TA-N analysis by the Kjeldahl procedure (Kjeltec 1030 Auto Analyzer, Tecator, Höganäs, Sweden; AOAC, 1990; method 988.05). To determine TCA-N, $0.5 \mathrm{~mL}$ of $50 \%$ (wt/vol) TCA solution was added to $2 \mathrm{~mL}$ of filtered subsample. After standing for $4 \mathrm{~h}$ at $5^{\circ} \mathrm{C}$, the tubes were centrifuged at $9,000 \times g$ for $15 \mathrm{~min}$ at $4^{\circ} \mathrm{C}$. The 
supernatant was frozen until analyzed for TCA-N by the Kjeldahl procedure. Results were used to calculate the large peptides-N (LPep N; between 3 and 10 AA) and small peptides (between 2 and 3 AA) plus amino acids $\mathbf{N}(\mathbf{S P e p}+\mathbf{A A} \mathbf{N})$ as reported by Licitra et al. (1996) using the following formulas: LPep $\mathrm{N}=$ [TCA$\mathrm{N}]-[\mathrm{TA}-\mathrm{N}] ;$ and SPep $+\mathrm{AA} \mathrm{N}=[\mathrm{TA}-\mathrm{N}]-[$ ammonia $\mathrm{N}]$ (in $\mathrm{mg} / 100 \mathrm{~mL}$ ).

\section{Tissue and Microbial Sampling and Analyses}

At the end of the trial (d 70), 3 male calves from each treatment were slaughtered to collect tissue and contents from the gastrointestinal tract. Macroscopic and microscopic aspects of different parts of digestive tract were evaluated as described by Beiranvand et al. (2014). Samples were taken for histological examination from 5 different parts of the rumen (caudodorsal sac, cranial part of dorsal sac, cranial part of ventral sac, caudal portion of caudoventral blind sac, and ventral portion of caudoventral blind sac), 3 different parts of the small intestine (duodenum, jejunum, and ileum), and liver. These samples were flushed with normal saline and fixed in 10\% buffered formalin (Merck, Darmstadt, Germany) for $96 \mathrm{~h}$. Tissue samples were then embedded in paraffin, and were sectioned $(6 \mu \mathrm{m})$ and stained with hematoxylin and eosin for observation under a light microscope (Olympus, Tokyo, Japan) equipped with a camera to take microphotographs. Microscopic images were analyzed using image analyzer software (TS View) according to Beiranvand et al. (2014) and Steele et al. (2016).

Liver samples approximately $2 \times 2 \mathrm{~cm}$ in size were also separated from the large lobe, rinsed with normal saline, immediately frozen in liquid nitrogen, and stored at $-80^{\circ} \mathrm{C}$ for subsequent analysis. Liver DM was determined after freeze-drying the samples had constant weight. Liver lipids and glycogen were measured as described by Rosendo and Mcdowell (2003) and Greene et al. (2017), respectively. Released glucose was measured using commercial kit (Pars Azmoon Co.).

Concurrent with the tissue sampling, some contents of the colon and 3 different parts of the small intestine were collected in separate sterile tubes for analyzing microbial population. Samples were fully mixed with glycerol at the ratio of 1:1 to protect against frost. After freezing in liquid nitrogen they were kept at $-80^{\circ} \mathrm{C}$ until subsequent tests (Kirsop and Snell, 1984). Four culture media were prepared based on the manufacturer's instructions (Scharlab, Barcelona, Spain) and used for corresponding bacterial plate count according to specified protocols; nutrient agar for bacilli and aerobic bacteria after $24 \mathrm{~h}$ incubation at $30^{\circ} \mathrm{C}$ under aerobic condition (Yang et al., 2010), eosin methylene blue agar for Escherichia coli after $24 \mathrm{~h}$ incubation at $37^{\circ} \mathrm{C}$ under aerobic condition (Ntuli et al., 2016), xylose lysine deoxycholate modified agar for coliforms after 24 $\mathrm{h}$ incubation at $37^{\circ} \mathrm{C}$ under aerobic conditions (Purdy et al., 2010), and de Man, Rogosa and Sharpe agar for lactobacilli after incubation at $30^{\circ} \mathrm{C}$ for $48 \mathrm{~h}$ under anaerobic conditions (Yang et al., 2010). The glycerolmixed samples were allowed to reach the ambient temperature and then serially diluted with a saline solution $(\mathrm{NaCl} 0.9 \%)$ to determine the best possible dilution rate; for duodenum, ileum, and jejunum, and the colon was $10^{-1}, 10^{-2}$, and $10^{-3}$, respectively. Before statistical analysis, the microbial data were first transformed to logarithmic values $\left(\log _{10}\right)$ and expressed as $\log _{10} \mathrm{cfu} / \mathrm{g}$ of fresh matter.

\section{Statistical Analyses}

All statistical analyses were conducted using SAS software (version 9.3, SAS Institute Inc., Cary, NC). Total DMI, starter feed intake, ADG, and feed efficiency data were analyzed using MIXED procedure of SAS (version 9.2, SAS Institute Inc.) with repeated measures for the preweaning (from d 1 to 56 of the study), postweaning (from d 57 to 70 of the study), and overall (from d 1 to 70 ) periods. The statistical model the effects of treatments, sex, period, and interaction between treatments and period as fixed effects and calf within treatments as a random effect. Initial values of body measurements were considered as covariates. Contrast statements were used to test the linear and quadratic effects of HCSP concentration in the diets. The effect of treatments on the categorical responses related to health scores was analyzed by repeated measures using PROC GLIMMIX with Poisson distribution and $\log$ link function. Log-transformed microbial data were analyzed using the MIXED model procedure with treatments as a fixed effect and calf within treatments as a random effect. The differences among treatment means were determined using least squares means test. Significance and trends was declared at $P \leq 0.05$ and $0.05<P \leq 0.10$, respectively.

\section{RESULTS}

\section{Performance, Skeletal Growth, and Health-Related Scores}

Data on starter intake, total DMI, ADG, FE, BW, and skeletal growth parameters are shown in Table 3. Increasing amount of HCSP decreased the starter intake in a linear manner during the postweaning and overall periods $(P=0.02$ and 0.05 , respectively). Weekly analysis showed that starter intake was lower in calves 
Table 3. Starter intake, total DMI, ADG, feed efficiency, BW, and skeletal growth variables in calves fed different starters

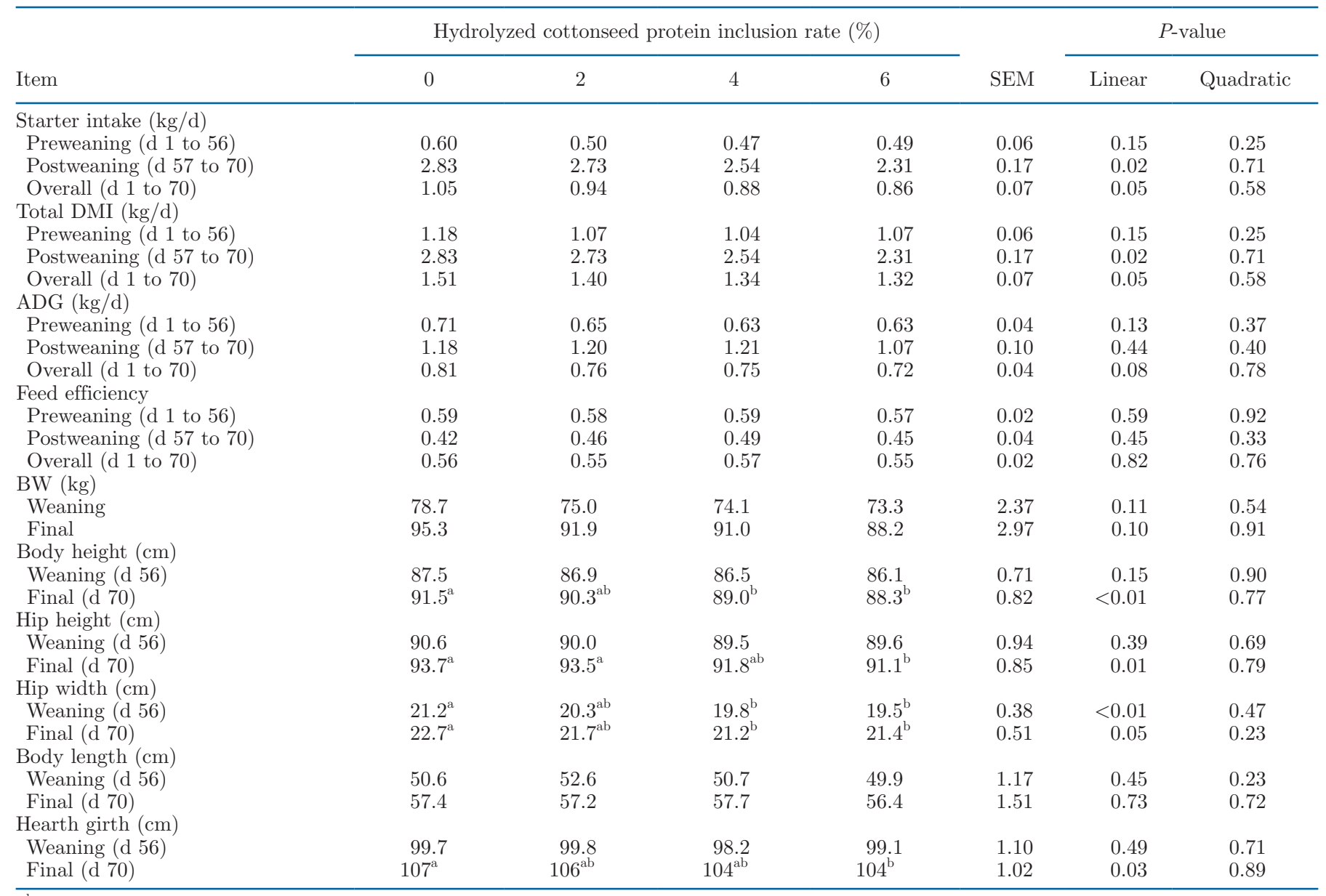

$\overline{\mathrm{a}, \mathrm{b}}$ Mean values with different superscripts within a row are significantly different $(P<0.05)$.

receiving 4 and $6 \%$ of HCSP compared with cows in the control group $(P=0.06$ and $P<0.01$; Figure 1$)$ at wk 1 and 3 of the study. Preweaning and postweaning ADG did not differ among dietary treatments; however, overall ADG tended to linearly decrease as dietary supplementation of HCSP increased $(P=0.08)$. Feed efficiency did not differ among the dietary treatments at preweaning or postweaning and overall periods. When calves received incremental levels of HCSP, final BW tended to linearly decrease $(P=0.10)$.

As HCSP supplementation increased, final body height $(P<0.01)$, hip height $(P=0.01)$, and hearth girth $(P=0.03)$ linearly decreased. Moreover, weaning and final hip width linearly decreased for calves supplemented with increasing levels of HCSP $(P<0.01$ and $P=0.05$, respectively). The negative effects of consuming HCSP on postweaning and overall starter intake, final BW, and final skeletal growth parameters were more evident in calves that received $6 \%$ HCSP compared with those in 0\% HCSP group.
Health-related measures are presented in Table 4. During the experimental period, the cough score tended to be quadratically affected by HCSP supplementation with calves fed $4 \%$ of HCSP had the lowest score $(P$ $=0.07$ ). Similarly, a quadratic effect was observed for fecal score with calves fed $2 \%$ HCSP had the highest score compared with the other HCSP groups $(P=$ $0.07)$.

\section{Blood-Related Parameters}

Blood metabolites, hormones, and hematological parameters are shown in Tables 5 and 6 . Serum glucose concentration tended to linearly increase with HCSP at $\mathrm{d} 70$ of the experiment $(P=0.07)$. Serum insulin, triiodothyronine, and thyroxine as well as BHB concentrations were not affected by dietary treatments during the experiment. At d 28, BUN concentration decreased as HCSP increased in the diet $(P=0.05)$. Increasing dietary HCSP supplementation caused a quadratic re- 
Table 4. Health-related scores of calves fed diets containing different hydrolyzed cottonseed protein concentrations

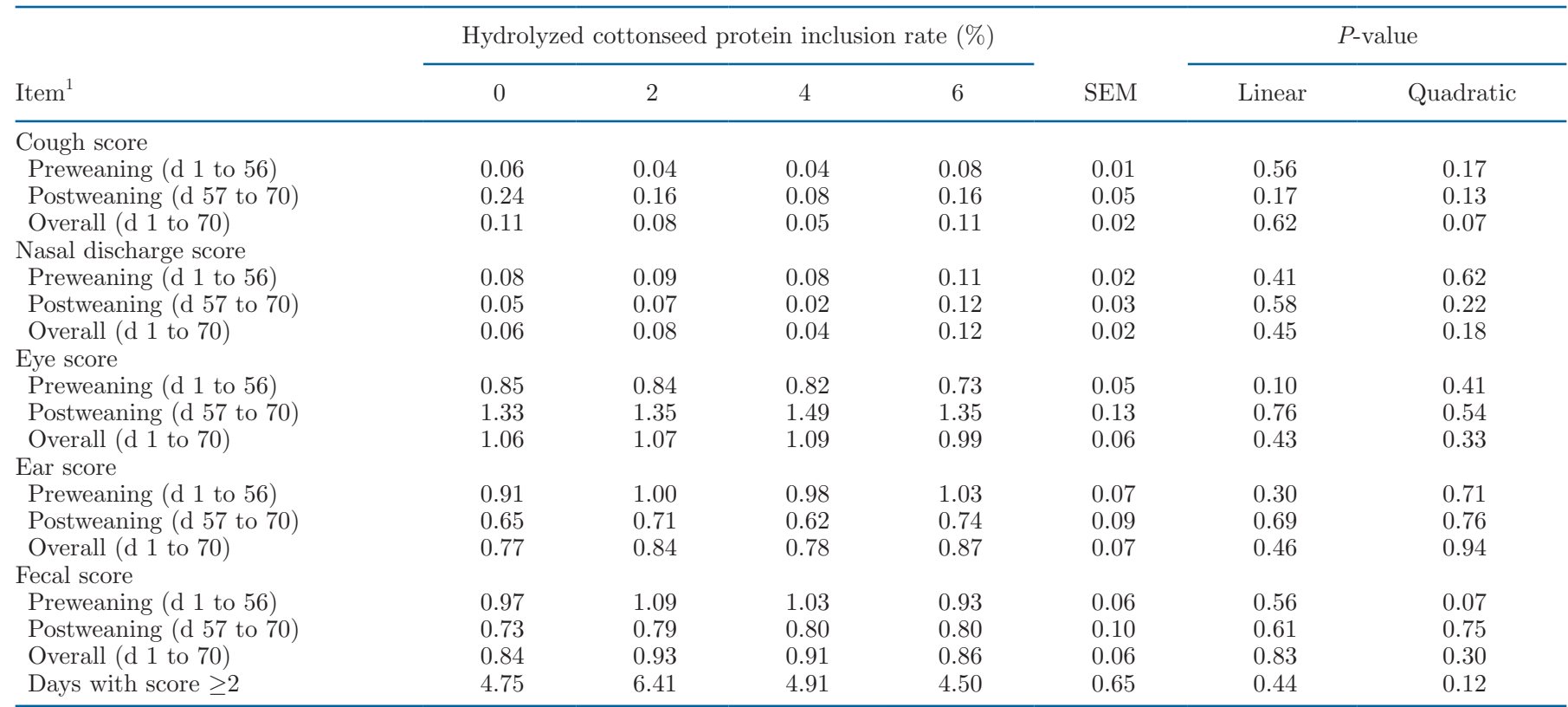

${ }^{1}$ Scoring was conducted at $\mathrm{d}$ 0, 3 and then 3 times a week for evaluation of 4 different health aspects (respiratory system, eye/ear, nose, and feces) as described by the Calf Health Scoring Chart of the University of Wisconsin following the scale of $0=$ normal and $3=$ acute health problems.

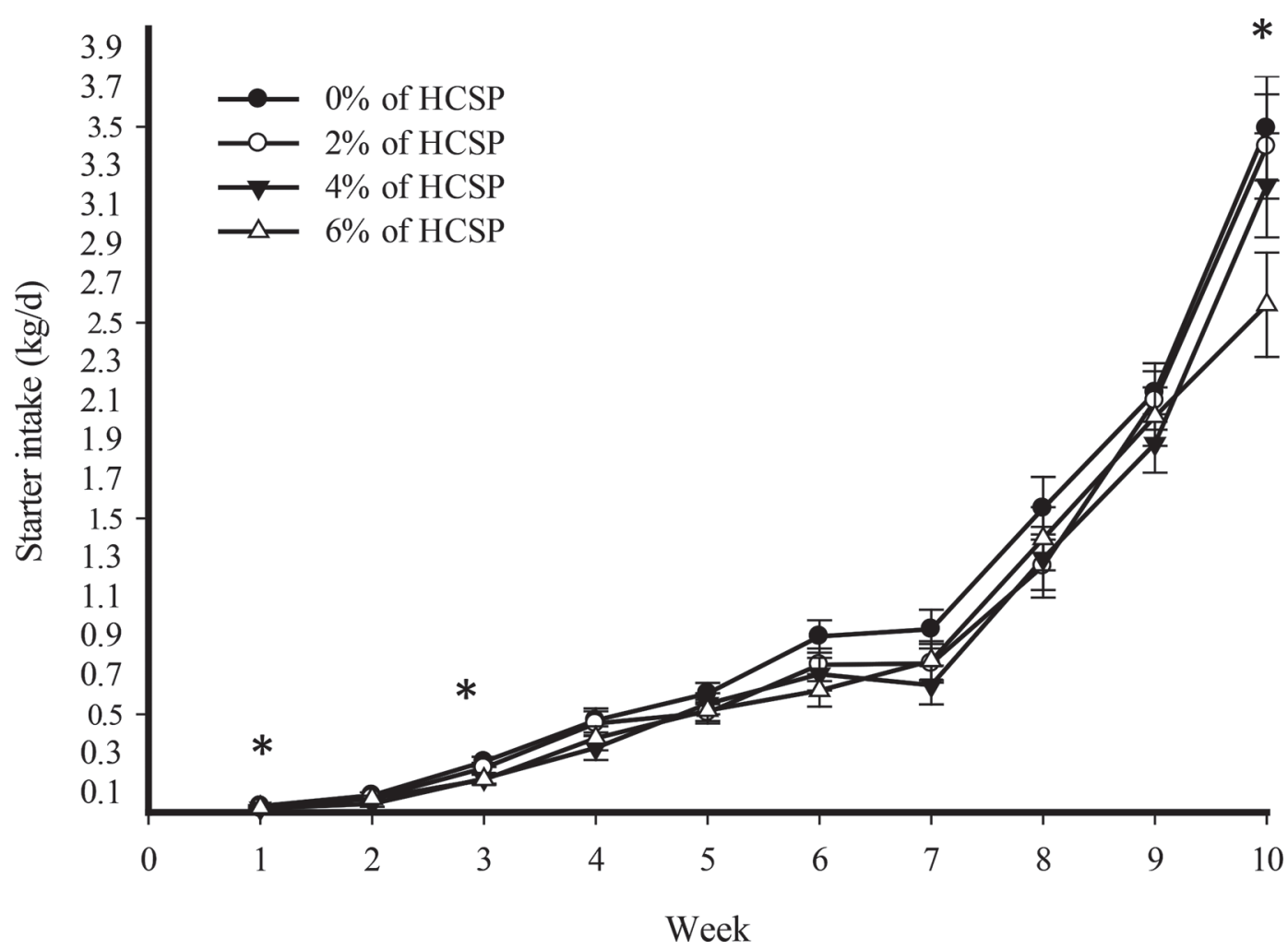

Figure 1. Weekly starter intake (LSM \pm SEM) of calves supplemented with incremental levels of hydrolyzed cottonseed protein (HCSP). *Linear effect $(P<0.05)$. 
sponse in cortisol concentration $(P=0.04)$ with lower values for 2 and $4 \% \mathrm{HCSP}$ at $28 \mathrm{~d}$ of experiment. At 56 and $70 \mathrm{~d}$ of experiment, serum cortisol concentration linearly increased when dietary HCSP increased and the greatest cortisol concentration was observed when calves received $6 \%$ of $\operatorname{HCSP}(P<0.01$ and $P=0.04$, respectively). Serum total protein, globulin, and albumin to globulin ratio were not different among dietary treatments. However, on d 56 of the experiment, serum albumin tended to increase in a quadratic manner by
HCSP supplementation and calves supplemented with $2 \%$ HCSP had the greatest albumin concentration $(P$ $=0.09$ ).

Cholesterol concentration tended to linearly decrease with increasing HCSP supplementation at d 28 of the experiment $(P=0.08)$. Results showed that serum activity of AST and ALT as well as AST to ALT ratio did not differ by dietary treatment. Serum malondialdehyde concentration did not differ among treatments, but serum total antioxidant capacity increased qua-

Table 5. Serum levels of blood metabolites related to energy and protein metabolism, hormones, and serum protein fractions at d 28, 56, and 70 in calves fed diets containing different hydrolyzed cottonseed protein concentrations

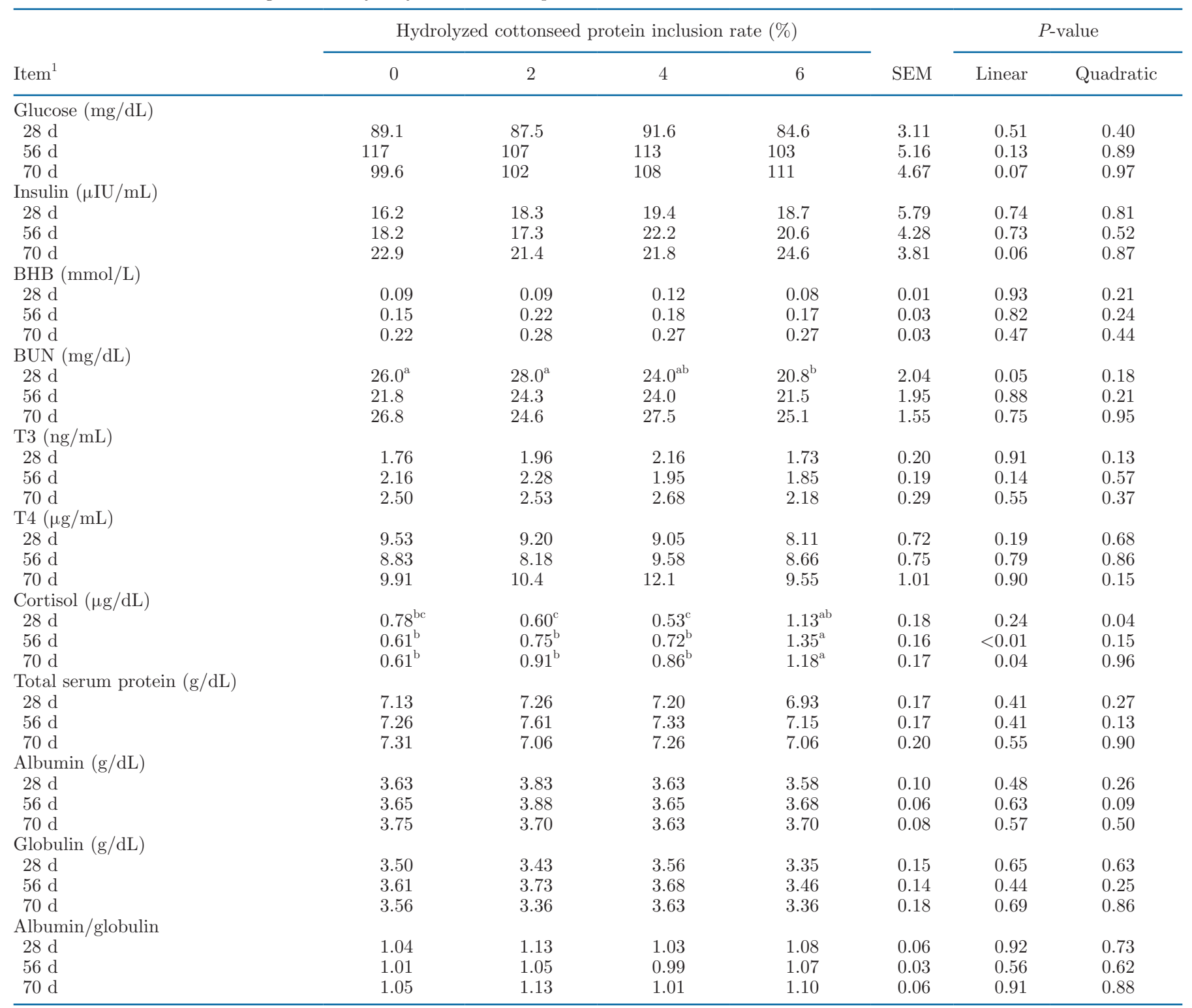

${ }^{\mathrm{a}-\mathrm{c}}$ Mean values with different superscripts within a row are significantly different $(P<0.05)$.

${ }^{1} \mathrm{~T} 3=$ triiodothyronine; $\mathrm{T} 4=$ thyroxine 
dratically; calves fed 2 and $4 \%$ HCSP had greater total antioxidant capacity than other treatments at d 56 and 70 of experiment $(P=0.06$ and $P<0.01$, respectively).

In addition, there was no difference among treatments for hematological data.

\section{Rumen and Small Intestine Development, Ruminal $\mathrm{pH}$ and Peptides Concentration, Liver Weight and Composition, and Microbial Count of Intestine}

Data related to gastrointestinal tract compartment weight, rumen and small intestine development parameters, rumen $\mathrm{pH}$ and peptide concentrations, liver chemical composition, and intestine microbial popula- tions are presented in Tables 7 and 8. Dietary treatments did not affect the full and empty weight of digestive tract compartments as a percentage of live weight of dairy calves, except for a linear decrease in empty reticulo-rumen $(P=0.02)$ and omasum weights $(P=$ $0.01)$ with increasing supplementation of HCSP. Data related to histo-morphological parameters of the rumen and small intestine showed that rumen muscle layer thickness and rumen wall thickness linearly decreased with higher $\operatorname{HCSP}(P=0.02)$. A linear reduction of jejunum villus height from 477.7 to $294.8 \mu \mathrm{m}$ was observed as HCSP increased $(P=0.09)$.

Rumen $\mathrm{pH}$ tended to linearly decrease $(P=0.10)$ with increasing dietary HCSP at d 70 of the experi-

Table 6. Serum levels of blood metabolites related to lipid metabolism, liver enzymes, and antioxidant status at d 28 , 56 , and 70 as well as hematological parameters (complete blood count; CBC) at d 70 in calves fed diets containing different hydrolyzed cottonseed protein concentration

\begin{tabular}{|c|c|c|c|c|c|c|c|}
\hline \multirow[b]{2}{*}{ Item $^{1}$} & \multicolumn{4}{|c|}{ Hydrolyzed cottonseed protein inclusion rate (\%) } & \multirow[b]{2}{*}{ SEM } & \multicolumn{2}{|c|}{$P$-value } \\
\hline & 0 & 2 & 4 & 6 & & Linear & Quadratic \\
\hline \multicolumn{8}{|l|}{ Cholesterol (mg/dL) } \\
\hline $28 \mathrm{~d}$ & 129 & 125 & 127 & 110 & 6.59 & 0.08 & 0.31 \\
\hline $56 \mathrm{~d}$ & 107 & 100 & 96.0 & 98.7 & 7.71 & 0.39 & 0.53 \\
\hline $70 \mathrm{~d}$ & 70.3 & 71.2 & 67.2 & 72.2 & 4.33 & 0.93 & 0.63 \\
\hline \multicolumn{8}{|l|}{ Triglyceride (mg/dL) } \\
\hline $28 \mathrm{~d}$ & 27.2 & 23.3 & 18.5 & 20.2 & 4.13 & 0.17 & 0.51 \\
\hline $56 \mathrm{~d}$ & 31.2 & 26.2 & 29.5 & 34.2 & 3.27 & 0.40 & 0.15 \\
\hline $70 \mathrm{~d}$ & 24.7 & 24.2 & 33.7 & 31.0 & 4.69 & 0.18 & 0.81 \\
\hline \multicolumn{8}{|l|}{$\operatorname{AST}(\mathrm{U} / \mathrm{L})$} \\
\hline $28 \mathrm{~d}$ & 33.7 & 39.3 & 35.2 & 40.0 & 3.09 & 0.29 & 0.89 \\
\hline $56 \mathrm{~d}$ & 45.0 & 47.3 & 43.2 & 50.3 & 1.89 & 0.17 & 0.21 \\
\hline $70 \mathrm{~d}$ & 56.0 & 64.3 & 60.2 & 63.5 & 2.99 & 0.18 & 0.41 \\
\hline \multicolumn{8}{|l|}{$\operatorname{ALT}(\mathrm{U} / \mathrm{L})$} \\
\hline $28 \mathrm{~d}$ & 7.33 & 11.2 & 8.50 & 9.00 & 1.25 & 0.68 & 0.19 \\
\hline $56 \mathrm{~d}$ & 11.0 & 14.2 & 11.0 & 13.5 & 1.13 & 0.40 & 0.77 \\
\hline $70 \mathrm{~d}$ & 16.7 & 17.2 & 17.2 & 18.7 & 1.37 & 0.34 & 0.71 \\
\hline \multicolumn{8}{|l|}{ MDA (nmol/mL) } \\
\hline $28 \mathrm{~d}$ & 1.11 & 1.30 & 1.15 & 1.10 & 0.12 & 0.73 & 0.37 \\
\hline $56 \mathrm{~d}$ & 1.30 & 1.35 & 1.28 & 1.33 & 0.11 & 0.94 & 1.00 \\
\hline $70 \mathrm{~d}$ & 1.20 & 1.15 & 1.43 & 1.28 & 0.15 & 0.44 & 0.74 \\
\hline \multicolumn{8}{|c|}{ Total antioxidant (mmol/L) } \\
\hline $28 \mathrm{~d}$ & 0.59 & 0.58 & 0.57 & 0.59 & 0.03 & 1.00 & 0.61 \\
\hline $56 \mathrm{~d}$ & 0.45 & 0.57 & 0.53 & 0.48 & 0.04 & 0.79 & 0.06 \\
\hline $70 \mathrm{~d}$ & $0.49^{\mathrm{b}}$ & $0.58^{\mathrm{a}}$ & $0.58^{\mathrm{a}}$ & $0.49^{\mathrm{b}}$ & 0.03 & 0.99 & 0.01 \\
\hline \multicolumn{8}{|l|}{$\mathrm{CBC}(\mathrm{d} 70)$} \\
\hline $\operatorname{RBC}\left(10^{12} / \mathrm{L}\right)$ & 11.0 & 11.0 & 11.0 & 10.3 & 0.61 & 0.47 & 0.65 \\
\hline $\mathrm{MCV}(\mathrm{fL})$ & 31.7 & 33.9 & 32.0 & 31.2 & 1.87 & 0.68 & 0.45 \\
\hline $\mathrm{MCH}(\mathrm{pg})$ & 10.4 & 11.2 & 10.6 & 10.3 & 0.52 & 0.70 & 0.35 \\
\hline $\mathrm{MCHC}(\mathrm{g} / \mathrm{dL})$ & 32.9 & 33.0 & 33.1 & 33.1 & 0.53 & 0.79 & 0.86 \\
\hline $\mathrm{WBC}\left(10^{9} / \mathrm{L}\right)$ & 9.35 & 10.8 & 9.79 & 9.29 & 0.91 & 0.77 & 0.32 \\
\hline Neutrophils $\left(10^{9} / \mathrm{L}\right)$ & 3.14 & 3.57 & 2.96 & 3.01 & 0.82 & 0.78 & 0.82 \\
\hline Lymphocytes $\left(10^{9} / \mathrm{L}\right)$ & 5.84 & 6.77 & 6.46 & 5.95 & 0.44 & 0.98 & 0.14 \\
\hline Monocytes $\left(10^{9} / \mathrm{L}\right)$ & 0.13 & 0.14 & 0.16 & 0.17 & 0.06 & 0.64 & 0.97 \\
\hline Eosinophils $\left(10^{9} / \mathrm{L}\right)$ & 0.04 & 0.03 & 0.02 & 0.02 & 0.01 & 0.14 & 0.35 \\
\hline Basophils $\left(10^{9} / \mathrm{L}\right)$ & 1.96 & 2.23 & 1.73 & 1.30 & 0.27 & 0.07 & 0.24 \\
\hline $\operatorname{PLT}\left(10^{9} / \mathrm{L}\right)$ & 626 & 417 & 487 & 543 & 92.0 & 0.66 & 0.18 \\
\hline
\end{tabular}

\footnotetext{
$\overline{\mathrm{a}, \mathrm{b}}$ Mean values with different superscripts within a row are significantly different $(P<0.05)$.

${ }^{1} \mathrm{AST}=$ aspartate aminotransferase $; \mathrm{ALT}=$ alanine aminotransferase $\mathrm{MDA}=$ malondialdehyde $\mathrm{RBC}=$ red blood cell count; $\mathrm{MCV}=$ mean corpuscular volume; $\mathrm{MCH}=$ mean corpuscular hemoglobin; $\mathrm{MCHC}=$ mean corpuscular hemoglobin concentration; WBC = white blood cell count; and PLT = number of platelets.
} 
Table 7. Gastrointestinal tract weight, rumen development parameters, rumen $\mathrm{pH}$ and peptides concentration, and liver chemical composition in calves fed diets containing different hydrolyzed cottonseed protein levels

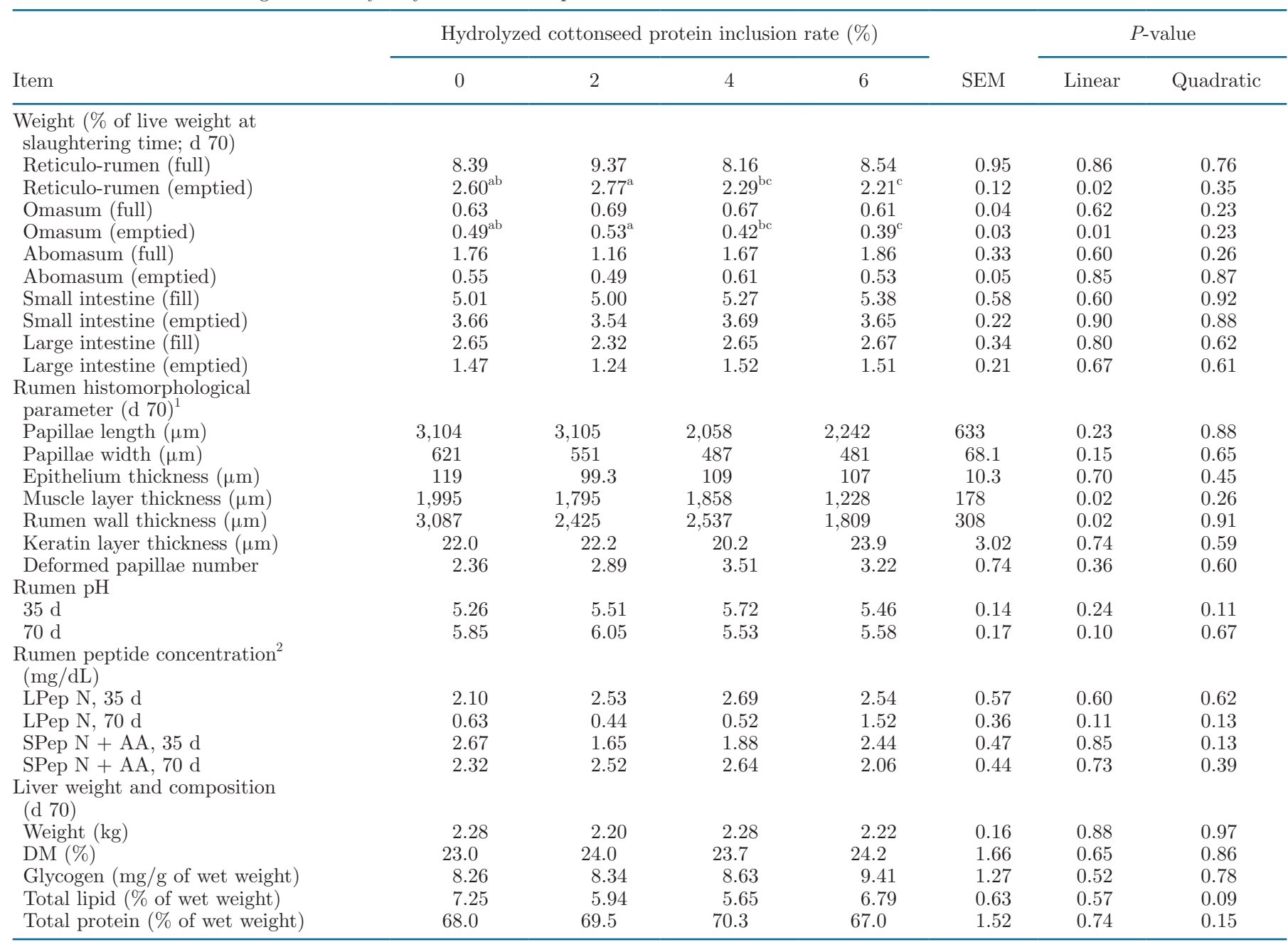

${ }^{\mathrm{a}-\mathrm{c}}$ Mean values with different superscripts within a row are significantly different $(P<0.05)$.

${ }^{1}$ Each figure in this part is representative of the average of 5 figures related to 5 different rumen parts: caudodorsal sac, cranial part of dorsal sac, cranial part of ventral sac, caudal portion of caudoventral blind sac, and ventral portion of caudoventral blind sac.

${ }^{2}$ LPep $\mathrm{N}=$ large peptides-N; SPep $\mathrm{N}+\mathrm{AA}=$ small peptides plus AA-N

ment. Results showed that LPep-N and SPep-N + AA were not affected by HCSP supplementation at d 35 and 70 of the experiment.

Increasing HCSP supplementation caused a quadratic response $(P=0.09)$ in total lipid content of the liver as a percent of wet weight, with lower values for the intermediate concentrations.

Microbiological counts of various intestinal compartments are shown in Table 8. Results showed that Enterobacter, Lactobacillus, and total bacterial counts of various intestinal compartments content did not differ among the dietary treatments $(P>0.10)$ under our experimental conditions; however, duodenal E. coli population tended to be quadratically affected by elevated dietary $\operatorname{HCSP}(P=0.09)$, with greater values for the intermediate concentrations.

\section{DISCUSSION}

The HCSP is derived from enzymatic hydrolysis of cottonseed protein and contained low fiber as well as minimal gossypol concentration compared with conventional CSM, which makes this product suitable for use as a protein supplement in the calf starter diet. Previous research indicated that feeding peptide-rich protein supplements to laying hens or young ruminants improved the production performance and metabolic responses (Lalles et al., 1995; Olukosi et al., 2018). 
This can be in part attributed to higher protein digestibility of these substances (Lalles et al., 1995) as well as more energy-efficient process of peptide absorption than proteins throughout the gastrointestinal tract (Daniel, 2004). In ruminants with functional rumen, peptides and AA supplementation could potentially stimulate the microbial protein synthesis and enhance the ruminal nitrogen and energy efficiency, especially in diets rich in fermentable carbohydrates (Wallace et al., 1999). In addition to their nutritional value, peptides can exert bioactive effects such as antihypertensive, antioxidative, immunomodulatory, antimicrobial, hypolipidemic, antithrombotic, and opioid-like activities (Hou et al., 2017). However, there is a need for a better understanding of the effect of peptides originating from enzymatic hydrolysis of cottonseed protein in young calves, as preruminant animals, or in older calves with a functional rumen. In the present study, $0,4.2,8.5$, and $12.8 \%$ of dietary $\mathrm{CP}$ was derived from incremental HCSP supplementation.

Table 8. Histo-morphologic and microbial populations evaluation of small intestine at d 70 in calves fed diets containing different hydrolyzed cottonseed protein concentrations

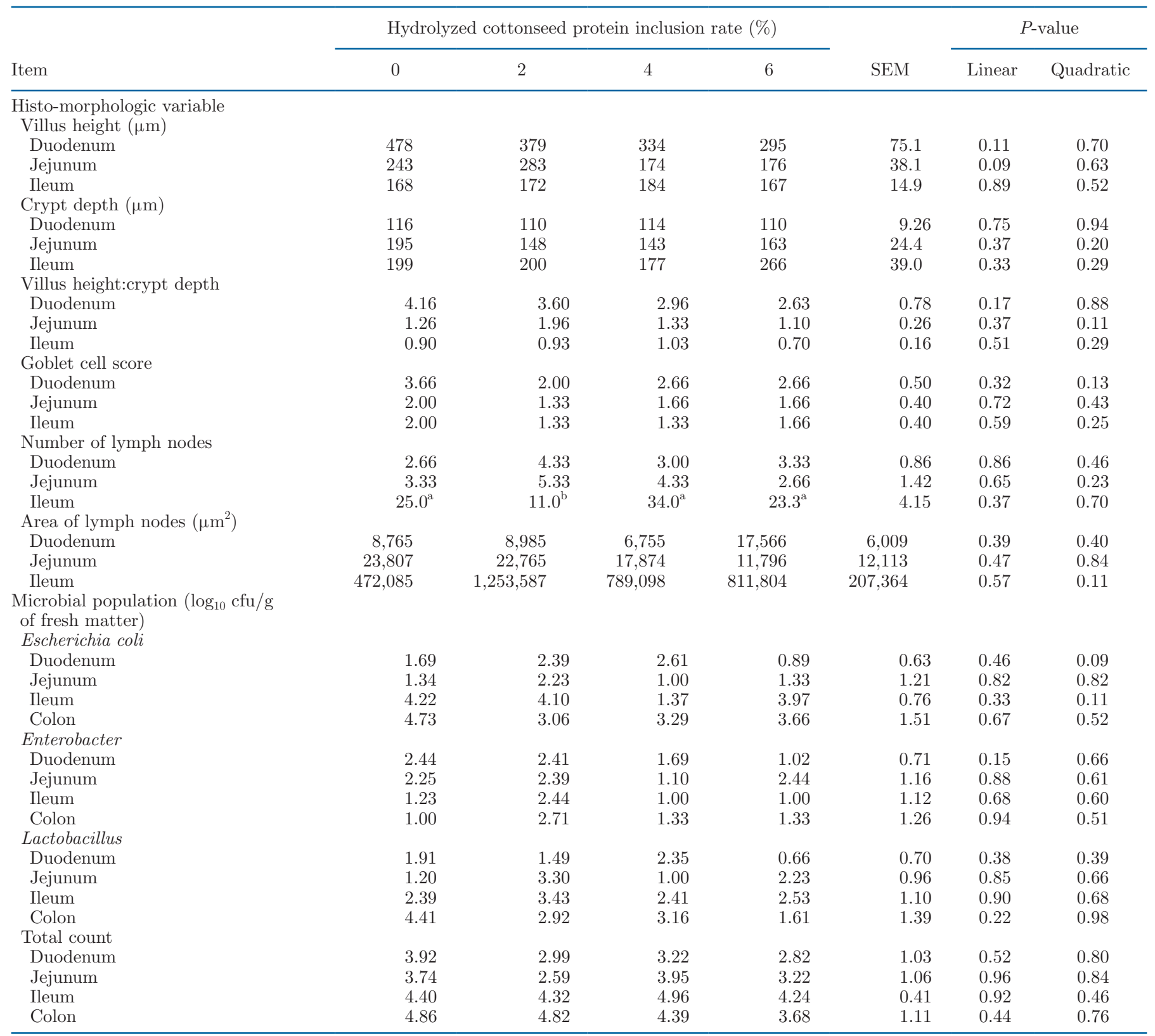

\footnotetext{
${ }^{\mathrm{a}, \mathrm{b}}$ Mean values with different superscripts within a row are significantly different $(P<0.05)$.
} 
At the postweaning period, supplementing calves with $6 \%$ of HCSP decreased the starter intake by $18 \%$ compared with that in cows in the control diet, which is in agreement with the results reported by Fokkink et al. (2009). These authors reported that calves supplemented with a peptide source at $4.5 \%$ of starter DM had lower starter intake at the pre- and postweaning period by 34 and $26 \%$, respectively; the peptide used had a distinct taste or aroma, which may have negatively affected the intake. The same pattern of starter intake was observed for ADG as calves supplemented with $6 \%$ of HCSP had lower overall ADG and final BW or skeletal growth parameters compared with control diet without HCSP supplementation (Table 3). Starter intake is recognized as one of the most important factors affecting ADG and the structural growth of young calves around weaning time (Lammers et al., 1998; Bateman et al., 2012). Fiems et al. (1986) reported slower ADG in calves received CSM compared with those that received soybean meal in the starter diet.

As discussed previously, impaired performance of calves received HCSP, especially at the postweaning period where starter intake is sharply elevated, might be due to poor AA profile or palatability problems of the product used. Although AA profile of diets was not measured in the present experiment, tabular AA concentrations relative to Lys indicate that AA profile was closer to the ideal protein balance of calf whole body in no-HCSP diets than other treatments (Table 1). On the other hand, CSM has lower concentration of EAA, especially lysine, than SBM (NRC, 2001; Broderick et al., 2013). Our results support the view that the adverse effects of poor AA profile of cottonseed protein on performance responses could be more profound in calves with nonfunctional rumen than adult ruminants (Drackley, 2008). In support of these speculations, previous studies demonstrated that ADG of calves fed CSM-based diet was lower than those fed soybean meal-based diet at 7 to $12 \mathrm{wk}$ of age (Fiems et al., 1986), whereas lactation performance was similar between dairy cows fed cottonseed or soybean meals (Brito and Broderick, 2007; Broderick et al., 2013).

Ample evidence indicates that many plant and animal protein hydrolyzates have significant antioxidant properties. For example, hydrolysates derived from cottonseed protein, particularly those with 0.8 to 1.2 $\mathrm{kDa}$, exert strong antioxidant activity as a natural antioxidant source and are suitable as a functional food additive (Gao et al., 2010). Results of the present study showed that mid-levels of HCSP (i.e., 2 and 4\%) enhanced the serum total antioxidant capacity of calves at the weaning and at the end of the experiment (Table 6 ). This response was not observed with the highest level of HCSP (i.e., 6\%), which is possibly due to a higher serum cortisol concentration that might deplete cellular glutathione and reduce total antioxidant capacity as previously noted by McAnulty et al. (2007).

Improvement of the antioxidant status in newborn calves may accelerate the maturation of their immune system, improve health status, and thus reduce calf losses (Mutinati et al., 2014). To our knowledge, little information is available on the effects of protein hydrolysate derived from enzymatic hydrolysis on the antioxidant status of preruminant or ruminant animals. In line with our results, Wang et al. (2017) showed that anti-oxidative abilities in serum or liver tissue of birds fed fermented CSM, rich in peptides, improved compared with that for birds fed unprocessed soybean meal or CSM (Wang et al., 2017). In a meta-analysis study, it has been demonstrated that glucocorticoids can induce oxidative stress condition (Costantini et al., 2011), which could be a reason for impaired antioxidant status of calves that received $6 \%$ HCSP compared with 2 and $4 \%$ levels.

Our results showed that the highest HCSP inclusion rate induced a stress condition as evidenced by greater serum cortisol concentration throughout the experimental period (Table 5). The elevated cortisol level in the calves may potentially affect immune system function and glucose metabolism (Yun et al., 2014). Cortisol enhances gluconeogenesis and inhibits the extrahepatic glucose utilization by disrupting insulin secretion or sensitivity (Weekes, 1991; Itoh et al., 2006). Therefore, lower growth performance of calves supplemented with $6 \%$ HCSP can be in part attributed to greater serum cortisol concentration as a stress indicator, which may impair glucose metabolism and insulin hemostasis; however, we did not measure any parameters related to insulin sensitivity.

Among blood cell types, only basophil count decreased in response of HCSP supplementation (Table 6 ), which can be in part attributed to the elevated serum cortisol concentration that might influence the basophil proliferation or differentiation (Abrahamsen et al., 1993; Kim et al., 2011).

In the present study, calves supplemented with the greatest HCSP level had lower reticulo-rumen and omasum weight expressed as a percent of live weight as well as lower rumen wall and muscle layer thickness compared with diets containing 0 and $2 \%$ of HCSP (Table 7), which is indicative of relatively poor ruminal development. Previous studies showed that greater physical stimulus (related to increased starter intake) is considered the main promotor of rumen development (Lesmeister and Heinrichs, 2004; Khan et al., 2008), which is in agreement with the results of starter intake 
in our experiment. Rumen development has a clear and major effect on the digestive capabilities and supply of substrates to the growing ruminant (Baldwin et al., 2004).

Ruminal $\mathrm{pH}$ is maintained by a balance between acid production by ruminal microbes and its absorption through the ruminal epithelial cells, neutralization with salivary buffers, and passage to the lower digestive tracts (Allen, 1997). Rumen epithelial development is critical for ruminal VFA absorption and transportation as well as their metabolism (Li et al., 2019). In the present study, lower ruminal $\mathrm{pH}$ in calves with higher HCSP supplementation can be, in part, attributed to poor ruminal epithelium development, which may adversely affect the absorptive capacity of ruminal VFA, resulting in the accumulation of acids in the rumen and consequently lower ruminal pH (Table 7). Recent studies demonstrated that goats exposed to SARA might experience a certain stress status, exhibiting an increase in acute phase protein and cortisol concentration (Jia et al., 2014). Therefore, ruminal acidosis in calves with higher HCSP supplementation could be a reason for elevated cortisol concentration.

Preruminant calves rely on glucose, deriving from liquid feed by intestinal absorption as the main energy source. Initiation of solid feed intake, especially a highly fermentable carbohydrate diet, stimulates the ruminal fermentation and VFA production, subsequently initiating rumen development (Khan et al., 2008). Therefore, calves with functional rumen exhibit a physiological shift in the primary energy source from glucose to VFA, resulting in lower blood glucose concentration relative to preruminant neonatal calves. In other words, in calves with poorly developed microbial population and epithelial tissues, more starch might escape the ruminal digestion and might be available at the intestinal level to yield glucose for absorption (Baldwin et al., 2004). In the present study, calves fed 0 and $2 \%$ of HCSP diets had lower glucose concentration compared with those in other treatments at the end of the study (Tables $5)$. This indicates a more ruminal macroscopic development. This speculation is supported with greater empty reticulo-rumen and omasum weights (Table 7). However, at d 56 and 70 of experiment, regardless of treatment effect, mean blood glucose concentrations were higher than normal range described in previous studies (Pezhveh et al., 2014; Nemati et al., 2015; Mojahedi et al., 2018). One possible explanation for this elevated glucose concentration observed in our study could be a difference in the time of obtaining blood samples. In agreement, Suarez-Mena et al. (2017) reported that, after weaning, blood glucose was affected by the time of the day as blood samples obtained before the morn- ing feeding had greater glucose concentration compared with samples obtained after morning ( 89.8 vs. $81.5 \mathrm{mg} /$ dL; Suarez-Mena et al., 2017).

In addition, calves supplemented with higher dietary HCSP had shorter duodenal and jejunal villi height compared with that for control calves (no HCSP; Table 8). The lower starter intake of calves fed HCSP could be responsible for these findings, as previous studies reported that feed or energy intake is one of the most important determinant of villi height in monogastric or ruminant animals (van Beers-Schreurs et al., 1998; Santos et al., 2018). Moreover, as discussed previously, calves supplemented with greatest HCSP level had higher cortisol concentration as an indicator of stress condition (Table 5). It has been repeatedly reported that stress condition may adversely affect feed intake, growth performance, immune responses, and gut development (Guil-Guerrero et al., 2016). For example, chronic stressors may have varying effects on the intestinal microarchitecture such as villi height, resulting in the impairment of intestinal health, efficiency of digestion, and absorption in chickens (Mitchell and Carlisle, 1992).

Neonatal calves are susceptible to diseases caused by many pathogens. Dietary antibiotics may improve feed intake and growth performance and enhance immune function (Donovan et al., 2002), and therefore result in decreased incidence of scours and mortality (Morrill et al., 1977, 1995). However, the use of antibiotics in the food supply chain is an emerging public health concern. Therefore, in an effort to eliminate antibiotics from calf diets, a few natural antimicrobial additives have been proposed to be added to colostrum, milk, or milk replacers as well as starter diets (Gruse et al., 2016; Yaghoubi et al., 2008; Bonelli et al., 2018). Antimicrobial peptides have been identified as possible substitutes for chemicals used as medications or food preservatives, owing to their high specificity, degradability in the environment, and low toxicity. Dietary supplementation with fermented CSM, as a peptiderich source, shifted the intestinal microbiota toward higher lactobacilli population and lower E. coli counts in the ileum and cecum of broilers at $21 \mathrm{~d}$ of age (Sun et al., 2013). These results are in agreement with lower duodenal $E$. coli counts observed only in calves receiving the greatest HCSP concentration in our study. In a newly published study, in vitro digestion of cottonseed protein hydrolysates considerably decreased its antimicrobial activity, but enhanced the radical scavenging capacity (Song et al., 2020). Therefore, gastrointestinal digestion of HCSP may decrease antimicrobial effects of this product especially at lower HCSP supplementation levels. 


\section{CONCLUSIONS}

The present study examined the effects of supplementing the incremental levels of enzymatically hydrolyzed cottonseed protein in the starter diet of neonatal calves on the performance, blood metabolites, and gastrointestinal tract development. Results of the present study showed that adding $2 \%$ of HCSP improved the antioxidant capacity of calves at the weaning and overall periods, but did not enhance the performance or rumen development parameters. Supplementing $6 \%$ of HCSP in the starter impaired the growth responses and ruminal and intestinal development while promoting a stress condition as evidenced by greater cortisol concentration. Overall, it appears that preruminant calves would not benefit from the addition of HCSP in their starter diet.

\section{ACKNOWLEDGMENTS}

Isfahan University of Technology and Pishgam Damparvar Sepahan Co. are acknowledged for funding this study. Goldasht-Nemooneh Agri-Animal Production Co. (Isfahan, Iran) and its personnel, especially S. Osivand, are also appreciated. The authors thank M. Nazari, M. Molavian, A. Kazemi, A. Piadeh, A. Rahmati (all from Isfahan University of Technology), and S. Hojjatifard (Khomeini-Shahr Azad Islamic University). The authors have no conflict of interest.

\section{REFERENCES}

Abrahamsen, J. F., R. Smaaland, S. Sandberg, A. Aakvaag, and K. Lote. 1993. Circadian variation in serum cortisol and circulating neutrophils are markers for circadian variation of bone marrow proliferation in cancer patients. Eur. J. Haematol. 50:206-212. https://doi.org/10.1111/j.1600-0609.1993.tb01922.x.

Allen, M. S. 1997. Relationship between fermentation acid production in the rumen and the requirement for physically effective fiber. J. Dairy Sci. 80:1447-1462. https://doi.org/10.3168/jds.S0022 -0302(97)76074-0.

AOAC. 1990. Official Methods of Analysis. 15th ed. Assoc. Off. Anal. Chem., Arlington, VA.

Baldwin, R. L., K. R. McLeod, J. L. Klotz, and R. N. Heitmann. 2004. Rumen development, intestinal growth and hepatic metabolism in the pre- and postweaning ruminant. J. Dairy Sci. 87(E. Suppl.):55-65.

Bateman, H. G. II, T. M. Hill, J. M. Aldrich, R. L. Schlotterbeck, and J. L. Firkins. 2012. Meta-analysis of the effect of initial serum protein concentration and empirical prediction model for growth of neonatal Holstein calves through 8 weeks of age. J. Dairy Sci. 95:363-369. https://doi.org/10.3168/jds.2011-4594.

Beiranvand, H., G. R. Ghorbani, M. Khorvash, A. Nabipour, M. Dehghan-Banadaky, A. Homayouni, and S. Kargar. 2014. Interactions of alfalfa hay and sodium propionate on dairy calf performance and rumen development. J. Dairy Sci. 97:2270-2280. https://doi .org/10.3168/jds.2012-6332.

Blackwelder, J. T., B. A. Hopkins, D. E. Diaz, L. W. Whitlow, and C. Brownie. 1998. Milk production and plasma gossypol of cows fed cottonseed and oilseed meals with or without rumen-undegradable protein. J. Dairy Sci. 81:2934-2941. https://doi.org/10.3168/jds .S0022-0302(98)75855-2.

Bonelli, F., L. Turini, G. Sarri, A. Serra, A. Buccioni, and M. Mele. 2018. Oral administration of chestnut tannins to reduce the duration of neonatal calf diarrhea. BMC Vet. Res. 14:227-332.

Brito, A. F., and G. A. Broderick. 2007. Effects of different protein supplements on milk production and nutrient utilization in lactating dairy cows. J. Dairy Sci. 90:1816-1827. https://doi.org/10 .3168/jds.2006-558.

Broderick, G. A., and J. H. Kang. 1980. Automated simultaneous determination of ammonia and total amino acids in ruminal fluid and in vitro media. J. Dairy Sci. 63:64-75. https://doi.org/10 .3168/jds.S0022-0302(80)82888-8.

Broderick, G. A., T. M. Kerkman, H. M. Sullivan, M. K. Dowd, and P. A. Funk. 2013. Effect of replacing soybean meal protein with protein from upland cottonseed, Pima cottonseed, or extruded Pima cottonseed on production of lactating dairy cows. J. Dairy Sci. 96:2374-2386. https://doi.org/10.3168/jds.2012-5723.

Burke, N. C., G. Scaglia, H. T. Boland, and W. S. Swecker Jr.. 2009. Influence of two-stage weaning with subsequent transport on body weight, plasma lipid peroxidation, plasma selenium, and on leukocyte glutathione peroxidase and glutathione reductase activity in beef calves. Vet. Immunol. Immunopathol. 127:365-370. https:// doi.org/10.1016/j.vetimm.2008.11.017.

Busquet, M., S. Calsamiglia, A. Ferret, and C. Kamel. 2006. Plant extracts affect in vitro rumen microbial fermentation. J. Dairy Sci. 89:761-771. https://doi.org/10.3168/jds.S0022-0302(06)72137-3.

Choi, C. W., S. Ahvenjarvi, A. Vanhatalo, V. Toivonen, and P. Huhtanen. 2002. Quantitation of the flow of soluble non-ammonia nitrogen entering the omasal canal of dairy cows fed grass silage based diets. Anim. Feed Sci. Technol. 96:203-220. https://doi.org/ 10.1016/S0377-8401(01)00348-0.

Coppock, C. E., J. K. Lanham, and J. L. Horner. 1987. A review of the nutritive value and utilization of whole cottonseed, cottonseed meal and associated by-products by dairy cattle. Anim. Feed Sci. Technol. 18:89-129. https://doi.org/10.1016/0377-8401(87)90041 -1 .

Costantini, D., V. Marasco, and A. P. Møller. 2011. A meta-analysis of glucocorticoids as modulators of oxidative stress in vertebrates. J. Comp. Physiol. B 181:447-456. https://doi.org/10.1007/s00360 $-011-0566-2$

Daniel, H. 2004. Molecular and integrative physiology of intestinal peptide transport. Annu. Rev. Physiol. 66:361-384. https://doi .org/10.1146/annurev.physiol.66.032102.144149.

Donovan, D. C., S. T. Franklin, C. C. L. Chase, and A. R. Hippen. 2002. Growth and health of Holstein calves fed milk replacers supplemented with antibiotics or enteroguard. J. Dairy Sci. 85:947950

Drackley, J. K. 2008. Calf nutrition from birth to breeding. Vet. Clin. North Am. Food Anim. Pract. 24:55-86.

Fiems, L. O., V. Boucqué, B. G. Cottyn, and F. X. Buysse. 1986. Cottonseed meal and maize gluten feed versus soybean meal as protein supplements in calf starters. Arch. Tierernahr. 36:731-740. https:/ /doi.org/10.1080/17450398609425314.

Fokkink, W. B., T. M. Hill, J. M. Aldrich, H. G. Bateman II, and R. L. Schlotterbeck. 2009. Effect of yeast culture, fatty acids, whey, and a peptide source on dairy calf performance. Prof. Anim. Sci. 25:794-800. https://doi.org/10.15232/S1080-7446(15)30791-9.

Gao, D., Y. Cao, and H. Li. 2010. Antioxidant activity of peptide fractions derived from cottonseed protein hydrolysate. J. Sci. Food Agric. 90:1855-1860. https://doi.org/10.1002/jsfa.4024.

Greene, J., J. Louis, O. Korostynska, and A. Mason. 2017. State-ofthe-art methods for skeletal muscle glycogen analysis in athletesThe need for novel non-invasive techniques. Biosensors (Basel) $7: 11$.

Gruse, J., E. Kanitz, J. M. Weitzel, A. Tuchscherer, T. Stefaniak, P. Jawor, S. Wolffram, and H. M. Hammon. 2016. Quercetin feeding in newborn dairy calves cannot compensate colostrum deprivation: Study on metabolic, antioxidative and inflammatory traits. PLoS One 11:e0146932. 
Guil-Guerrero, J. L., L. Ramos, C. Moreno, J. C. Zúñiga-Paredes, M. Carlosama-Yépez, and P. Ruales. 2016. Plant-food by-products to improve farm-animal health. Anim. Feed Sci. Technol. 220:121135. https://doi.org/10.1016/j.anifeedsci.2016.07.016.

Hou, Y., Z. Wu, Z. Dai, G. Wang, and G. Wu. 2017. Protein hydrolysates in animal nutrition: Industrial production, bioactive peptides, and functional significance. J. Anim. Sci. Biotechnol. 8:24. https://doi.org/10.1186/s40104-017-0153-9.

Hulbert, L. E., and S. J. Moisá. 2016. Stress, immunity, and the management of calves. J. Dairy Sci. 99:3199-3216. https://doi.org/10 $.3168 /$ jds.2015-10198.

Itoh, F., T. Komatsu, S. Kushibiki, and K. Hodate. 2006. Effects of ghrelin injection on plasma concentrations of glucose, pancreatic hormones and cortisol in Holstein dairy cattle. Comp. Biochem. Physiol., A Mol. Integr. Physiol. 143:97-102. https://doi.org/10 .1016/j.cbpa.2005.11.001.

Jia, Y. Y., S. Wang, Y. Ni, Y. Zhang, S. Zhuang, and X. Shen. 2014. High concentrate-induced subacute ruminal acidosis (SARA) increases plasma acute phase proteins (APPs) and cortisol in goats. Animal 8:1433-1438. https://doi.org/10.1017/S1751731114001128.

Khan, M. A., H. J. Lee, W. S. Lee, H. S. Kim, S. B. Kim, S. B. Park, K. S. Baek, J. K. Ha, and Y. J. Choi. 2008. Starch source evaluation in calf starter: II. Ruminal parameters, rumen development, nutrient digestibilities, and nitrogen utilization in Holstein calves. J. Dairy Sci. 91:1140-1149. https://doi.org/10.3168/jds.2007-0337.

Kim, M. H., J. Y. Yang, S. D. Upadhaya, H. J. Lee, C. H. Yun, and J. K. Ha. 2011. The stress of weaning influences serum levels of acute-phase proteins, iron-binding proteins, inflammatory cytokines, cortisol, and leukocyte subsets in Holstein calves. J. Vet. Sci. 12:151-157. https://doi.org/10.4142/jvs.2011.12.2.151.

Kim, S. W., E. van Heugten, F. Ji, C. H. Lee, and R. D. Mateo. 2010. Fermented soybean meal as a vegetable protein source for nursery pigs: I. Effects on growth performance of nursery pigs. J. Anim. Sci. 88:214-224. https://doi.org/10.2527/jas.2009-1993.

Kirsop, B. E., and J. J. S. Snell, ed. 1984. Maintenance of microorganisms. Academic Press Inc., (London) Ltd., London, UK.

Lalles, J. P., R. Toullec, P. Branco Pardal, and J. W. Sissons. 1995. Hydrolyzed soy protein isolate sustains high nutritional performance in veal calves. J. Dairy Sci. 78:194-204. https://doi.org/10 $.3168 /$ jds.S0022-0302(95)76629-2.

Lammers, B., A. Heinrichs, and A. Aydin. 1998. The effect of whey protein concentrate or dried skim milk in milk replacer on calf performance and blood metabolites. J. Dairy Sci. 81:1940-1945. https://doi.org/10.3168/jds.S0022-0302(98)75767-4.

Lesmeister, K., and A. Heinrichs. 2004. Effects of corn processing on growth characteristics, rumen development, and rumen parameters in neonatal dairy calves. J. Dairy Sci. 87:3439-3450. https:// doi.org/10.3168/jds.S0022-0302(04)73479-7.

Li, W., S. Gelsinger, A. Edwards, C. Riehle, and D. Koch. 2019. Transcriptome analysis of rumen epithelium and meta-transcriptome analysis of rumen epimural microbial community in young calves with feed induced acidosis. Sci. Rep. 9:4744. https://doi.org/10 .1038/s41598-019-40375-2.

Licitra, G., T. M. Hernandez, and P. J. Van Soest. 1996. Standardization of procedures for nitrogen fractionation of ruminant feeds. Anim. Feed Sci. Technol. 57:347-358. https://doi.org/10.1016/ 0377-8401(95)00837-3.

Maesoomi, S. M., G. R. Ghorbani, M. Alikhani, and A. Nikkhah. 2006. Short communication: Canola meal as a substitute for cottonseed meal in diet of midlactation Holsteins. J. Dairy Sci. 89:1673-1677. https://doi.org/10.3168/jds.S0022-0302(06)72234-2.

McAnulty, S., L. McAnulty, D. Nieman, J. Morrow, C. Dumke, and A. Utter. 2007. Carbohydrate effect: Hormone and oxidative changes. Int. J. Sports Med. 28:921-927. https://doi.org/10.1055/s-2007 $-964987$.

Meagher, E. A., and G. A. FitzGerald. 2000. Indices of lipid peroxidation in vivo: Strengths and limitations. Free Radic. Biol. Med. 28:1745-1750. https://doi.org/10.1016/S0891-5849(00)00232-X.

Mirzaei, M., M. Khorvash, G. R. Ghorbani, M. Kazemi-Bonchenari, A. Riasi, A. Soltani, B. Moshiri, and M. H. Ghaffari. 2016. Interactions between the physical form of starter (mashed versus textured) and corn silage provision on performance, rumen fermentation, and structural growth of Holstein calves. J. Anim. Sci. 94:678-686. https://doi.org/10.2527/jas.2015-9670.

Mitchell, M. A., and A. J. Carlisle. 1992. The effects of chronic exposure to elevated environmental temperature on intestinal morphology and nutrient absorption in the domestic fowl (Gallus domesticus). Comp. Biochem. Physiol. A Physiol. 101:137-142.

Mojahedi, S., M. Khorvash, G. R. Ghorbani, E. Ghasemi, M. Mirzaei, and F. Hashemzadeh-Cigari. 2018. Performance, nutritional behavior, and metabolic responses of calves supplemented with forage depend on starch fermentability. J. Dairy Sci. 101:7061-7072. https://doi.org/10.3168/jds.2017-13798.

Morrill, J. L., A. D. Dayton, and R. Mickelson. 1977. Cultured milk and antibiotics for young calves. J. Dairy Sci. 60:1105-1109.

Morrill, J. L., J. M. Morrill, A. M. Feyerham, and J. F. Laster. 1995. Plasma protein and probiotics as ingredients in milk replacer. J. Dairy Sci. 78:902-907.

Mutinati, M., M. Pantaleo, M. Roncetti, M. Piccinno, A. Rizzo, and R. L. Sciorsci. 2014. Oxidative stress in neonatology. A review. Reprod. Domest. Anim. 49:7-16. https://doi.org/10.1111/rda.12230.

Nemati, M., H. Amanlou, M. Khorvash, B. Moshiri, M. Mirzaei, M. A. Khan, and M. H. Ghaffari. 2015. Rumen fermentation, blood metabolites, and growth performance of calves during transition from liquid to solid feed: Effects of dietary level and particle size of alfalfa hay. J. Dairy Sci. 98:7131-7141. https://doi.org/10.3168/ jds.2014-9144.

NRC. 2001. Nutrient Requirements of Dairy Cattle. 7th rev. ed. Natl. Acad. Press, Washington, DC.

Ntuli, V., P. M. K. Njage, and E. M. Buys. 2016. Characterization of Escherichia coli and other Enterobacteriaceae in producer-distributor bulk milk. J. Dairy Sci. 99:9534-9549.

Oh, Y. G., K. H. Kim, J. H. Kim, J. J. Choung, and D. G. Chamberlain. 1999. The effect of the form of nitrogen in the diet on ruminal fermentation and the yield of microbial protein in sheep consuming diets of grass silage supplemented with starch or sucrose. Anim. Feed Sci. Technol. 78:227-237. https://doi.org/10.1016/S0377 -8401(98)00283-1.

Olukosi, O. A., W. Xiao, and J. Jia. 2018. Peptide supplementation to nutrient-adequate diets enhanced internal egg quality during storage in hens at peak production. J. Sci. Food Agric. 98:1850-1855. https://doi.org/10.1002/jsfa.8661.

Pezhveh, N., G. R. Ghorbani, P. Rezamand, and M. Khorvash. 2014. Effects of different physical forms of wheat grain in corn-based starter on performance of young Holstein dairy calves. J. Dairy Sci. 97:6382-6390. https://doi.org/10.3168/jds.2013-7718.

Plascencia, A., and R. A. Zinn. 1996. Influence of flake density on the feeding value of steam-processed corn in diets for lactating cows. J. Anim. Sci. 74:310-316. https://doi.org/10.2527/1996.742310x.

Purdy, C. W., R. N. Clark, and D. C. Straus. 2010. Determination of water quality variables, endotoxin concentration, and Enterobacteriaceae concentration and identification in southern High Plains dairy lagoons. J. Dairy Sci. 93:1511-1522. https://doi.org/ $10.3168 /$ jds.2009-2497.

Rosendo, O., and L. Mcdowell. 2003. Relationship between liver dry matter and liver lipids in periparturient dairy cows. Acta Vet. Brno 72:541-546. https://doi.org/10.2754/avb200372040541.

Santos, A., F. J. Giráldez, C. Valdés, E. Trevisi, L. Lucini, J. Frutos, and S. Andrés. 2018. Milk replacer restriction during early life impairs the live body weight and progesterone patterns of ewe lambs during the replacement period. J. Dairy Sci. 101:8021-8031. https: //doi.org/10.3168/jds.2018-14648.

Song, W., X. Kong, Y. Hua, X. Li, C. Zhang, and Y. Chen. 2020. Antioxidant and antibacterial activity and in vitro digestion stability of cottonseed protein hydrolysates. LWT 118:108724.

Steele, M. A., G. B. Penner, F. Chaucheyras-Durand, and L. L. Guan. 2016. Development and physiology of the rumen and the lower gut: Targets for improving gut health. J. Dairy Sci. 99:4955-4966. https://doi.org/10.3168/jds.2015-10351.

Suarez-Mena, F. X., W. Hu, T. S. Dennis, T. M. Hill, and R. L. Schlotterbeck. 2017. $\beta$-Hydroxybutyrate (BHB) and glucose concentrations in the blood of dairy calves as influenced by age, vaccination 
stress, weaning, and starter intake including evaluation of BHB and glucose markers of starter intake. J. Dairy Sci. 100:2614-2624. https://doi.org/10.3168/jds.2016-12181.

Sun, H., J. W. Tang, C. L. Fang, X. H. Yao, Y. F. Wu, X. Wang, and J. Feng. 2013. Molecular analysis of intestinal bacterial microbiota of broiler chickens fed diets containing fermented cottonseed meal. Poult. Sci. 92:392-401. https://doi.org/10.3382/ps.2012-02533.

Tang, J. W., H. Sun, X. H. Yao, Y. F. Wu, X. Wang, and J. Feng. 2012. Effects of replacement of soybean meal by fermented cottonseed meal on growth performance, serum biochemical parameters and immune function of yellow-feathered broilers. Asian-Australas. J. Anim. Sci. 25:393-400. https://doi.org/10.5713/ajas.2011.11381.

Van Amburgh, M. E., E. A. Collao-Saenz, R. J. Higgs, D. A. Ross, E. B. Recktenwald, E. Raffrenato, L. E. Chase, T. R. Overton, J. K Mills, and A. Foskolos. 2015. The Cornell Net Carbohydrate and Protein System: Updates to the model and evaluation of version 6.5. J. Dairy Sci. 98:6361-6380. https://doi.org/10.3168/jds.2015 -9378 .

van Beers-Schreurs, H. M. G., M. J. A. Nabuurs, L. Vellenga, H. J. K. Valk, T. Wensing, and H. J. Breukink. 1998. Weaning and the weanling diet influence the villous height and crypt depth in the small intestine of pigs and alter the concentrations of short-chain fatty acids in the large intestine and blood. J. Nutr. 128:947-953. https://doi.org/10.1093/jn/128.6.947.

Wallace, R. J., C. Atasoglu, and C. J. Newbold. 1999. Role of peptides in rumen microbial metabolism - Review. Asian-Australas. J. Anim. Sci. 12:139-147. https://doi.org/10.5713/ajas.1999.139.

Wang, Y., Q. Deng, D. Song, W. Wang, H. Zhou, L. Wang, and A. Li. 2017. Effects of fermented cottonseed meal on growth performance, serum biochemical parameters, immune functions, antioxidative abilities, and cecal microflora in broilers. Food Agric. Immunol. 28:725-738. https://doi.org/10.1080/09540105.2017.1311308.

Weekes, T. 1991. Hormonal control of glucose metabolism. Pages 183-200 in Physiological Aspects of Digestion and Metabolism in Ruminants. T. Tsuda, Y. Sasaki, and Kawashima, ed. Academic Press, San Diego, CA.

Windeyer, M. C., K. E. Leslie, S. M. Godden, D. C. Hodgins, K. D. Lissemore, and S. J. LeBlanc. 2014. Factors associated with morbidity, mortality, and growth of dairy heifer calves up to 3 months of age. Prev. Vet. Med. 113:231-240. https://doi.org/10.1016/j .prevetmed.2013.10.019.

Yaghoubi, S. M. J., G. R. Ghorbani, H. R. Rahmani, and A. Nikkhah. 2008. Growth, weaning performance and blood indicators of humoral immunity in Holstein calves fed supplemental flavonoids. J. Anim. Physiol. Anim. Nutr. (Berl.) 92:456-462.

Yang, J., Y. Cao, Y. Cai, and F. Terada. 2010. Natural populations of lactic acid bacteria isolated from vegetable residues and silage fermentation. J. Dairy Sci. 93:3136-3145. https://doi.org/10.3168/ jds. 2009-2898.

Yun, C.-H., P. Wynn, and J. K. Ha. 2014. Stress, acute phase proteins and immune modulation in calves. Anim. Prod. Sci. 54:1561-1568. https://doi.org/10.1071/AN14441.

Zelski, R. Z., J. T. Rothwell, R. E. Moore, and D. J. Kennedy. 1995 Gossypol toxicity in preruminant calves. Aust. Vet. J. 72:394-398. https://doi.org/10.1111/j.1751-0813.1995.tb06180.x. 